\title{
CONTRIBUTION OF ORGANIZATIONAL JUSTICE AND ORGANIZATIONAL SUPPORT TO EMPLOYEE ENGAGEMENT AND ITS IMPACT ON EMPLOYEES PERFORMANCE
}

\author{
Wirakusuma I Nyoman*, Surya Ida Bagus Ketut \\ Management Program, University of Udayana, Bali, Indonesia \\ *E-mail: nyomanwirakusuma@gmail.com
}

\begin{abstract}
The purpose of this study was to analyze how the contribution of organizational fairness and organizational support to employee engagement and its impact on employee performance. This research was conducted at PT. Astra International AUTO 2000 Cokroaminoto on sales staff of 50 employees with saturated sample method. Data were collected by distributing questionnaires and using Partial Least Square (PLS) as a technique of data analysis. The results of this study show that organizational fairness has a positive and significant impact on organizational support, organizational support has a positive and significant effect on employee engagement, organizational fairness has a positive and significant impact on employee engagement, in addition this research also revealed that employee engagement have a positive and significant impact on performance employees. the practical implications in this study of employees in AUTO 2000 companies perform well in group work) as well as upholding the way group work is compared to working individually. It appears that employees in the company AUTO 2000 have an attachment to their work. It is expected that the boss needs to know the importance of knowledge of justice and organizational support, when employees feel fair and get good support from employers so that employees will show good work which will have a positive impact on AUTO 2000 Cokroaminoto.
\end{abstract}

\section{KEY WORDS}

Organizational justice, organizational support, employee engagement, job, performance.

Every company will always try to get the best performance from its employees, in the hope that what the company's goals will be achieved. The role of human resources as one of the company's most important assets is not only seen from the results of work productivity but also seen from the quality of work produced. Therefore, employee performance is something that deserves important attention from the company. Given the importance of the role of employee performance for organizational success, understanding related factors that can improve employee performance itself is important and important (Ardi et al., 2017).

In responding to the challenges of higher productivity and quality of work, management can no longer rely on human resource management policies that are oriented to employee satisfaction or employee commitment to the organization. To overcome competition and answer the challenges of the organizational environment, management requires employees who have a high level of attachment to their work (Saroyeni, 2012). Individual involvement or employee involvement that allows individuals to develop emotional relationships with the organization in which they work, feel the same fate and responsibility in achieving success in achieving goals through investing in attention, emotional, technical and intellectual competencies on an ongoing basis. An understanding of the business environment, communication skills and emotional stability of individual employees will make a positive contribution to the transformation process to realize the vision of the organization so that they can be effective agents of change in pushing towards the expected conditions.

Ulrich (2007: 32) said that successful organizations depart from 3 important qualities that must be present in the employee, namely: competence, involvement, and contribution. It is important to realize that work performance and organizational success do not only depend on the competencies or cognitive skills that employees have, but also depend on how employees respond to the work and organization they work for. Organizations have long been interested in discussions about how thoughts and feelings employees feel about their 
work, and about whether employees have a desire to dedicate themselves to the organization. The study of this problem is closely related to a concept called employee involvement or in some instances which is often referred to as job involvement (Putri, 2013).

Engagement to employees will emerge when employees have high morale. This is in line with the opinion of Bowles \& Cooper (2009) who said that involvement is the result of high morale. Employees will work enthusiastically to produce more and better. Employee behavior is what is called the behavior of employees who have involvement. In other words, morale is an aspect that must first appear in employees before employees feel involved.

According to Macey et al., (2009) feelings of involvement are relationships, involvement, commitment, desire to contribute, a sense of belonging, loyalty, and a sense of pride in work and also the company. When employees are involved (involved) employees have an awareness of the purpose of their role to provide services so as to make employees provide all their best abilities. High attachments affect employees in completing work (tend to have satisfactory work quality) and will have an impact on the low desire to leave work (Schiemann, 2011).

Employee involvement in Indonesia has long been in the spotlight because the majority of employees in Indonesia have low employee involvement. The results of the Gallup survey presented recently at the Breakfast Meeting of the HR Director organized by PMSM Indonesia in Jakarta stated that nearly $80 \%$ of workers in Indonesia were categorized as not involved in the workplace. The details only $13 \%$ of workers were fully involved, $76 \%$ were not involved, and $11 \%$ were actively released. Compared to other countries in Asean, Indonesia's position in terms of workers involved is only better than Vietnam, still losing to Singapore, Thailand, Malaysia and the Philippines. This proves that there are still many employees and elements of companies or institutions in Indonesia that have not given more attention to employee involvement.

To foster employee engagement in the company, the management must develop a participatory leadership style, support employees and apply justice in determining policies to employees especially procedural justice consistently in each line of management (Saroyeni, 2012). When employees have a high perception of justice in the organization, it is certain that they feel obliged or required to be fair in playing their role by giving a greater portion of the engagement rate. On the other hand, the perception of low justice is caused by employees withdrawing and releasing themselves from their work roles (Margaretha et al, 2012).

\section{LITERATURE REVIEW}

Organizational Justice. Organizational justice describes the individual's perception of the treatment received from an organization and the behavioral reaction to that perception. Organizational justice can also be defined as an equality study in the workplace (Fatimah et al., 2011). The organizational framework refers to justice and ethical behavior in an organization. Organizational justice is defined as a personal feeling of fair wages and benefits (Farahbod, 2013). Organizational justice emphasizes manager decisions, perceived equality, the effects of justice and the relationship between individuals and their work environment and describes individual perceptions of justice in the workplace. Greenberg \& Baron (2003) describe organizational justice as individual perceptions of justice in the decision-making process and the distribution of results that have been received by individuals. Employees consider their organization fair when they believe that the results they receive and how they are received are fair. An important element of organizational justice is an individual's perception of justice. In other words, justice is subjective, and lies in individual perceptions (Sekarwangi, 2014).

Organizational Support. Organizational support can be defined as employees' perceptions of the extent to which the organization supports employees and the extent to which the organization is prepared to provide assistance when needed (Mujiasih, 2015). Perception of organizational support is a person's belief that the organization in which he works values his contribution and cares for his welfare. Perceived organizational support is also seen as a guarantee that the organization will help employees when they need help to 
carry out their work and tasks effectively (Rasheed et al., 2013). Perception of organizational support is considered as a global belief formed by each employee regarding their assessment of organizational policies and procedures established based on their experience of organizational policies and processes, the acceptance of resources, interaction with supervisors and their perception of the organization's concern for their welfare (Yasar et al., 2014).

Employee Engagement. Employees who have engagement with the organization will be committed emotionally and intellectually to the organization. With this commitment, employees will give their best effort beyond what is expected in a job. Organizational commitment is different from engagement which refers to the attitude and binding of someone to their organization. Engagement is not an attitude, this is the level at which someone pays attention and has an attachment to performance in their role (Welch, 2011). Engagement is also different from organizational citizenship behavior, OCB involves volunteerism and informal behavior that can help co-workers and organizations, while engagement focuses on the role of a person's formal performance beyond extra-role and voluntary behavior (Saks, 2006). Rafferty, et.al. in Saroyeni (2012) revealed differences in commitment and citizenship behavior with individual attachments because commitment and citizenship behavior is a unidirectional reaction from individual employees to the organization while individual attachment is the result of a two-way interaction process between management and employees. According to Margaretha et al. (2012) closer engagement is related to the construct of work engagement. Job involvement is defined as a cognitive or belief in the identification of psychology. This is a little different from engagement because it is more related to how someone empowers them when they work which includes emotional and behavioral aspects. Employee engagement is the result of a cognitive decision about one's ability to satisfy the needs of work and is tied to one's self-image (Putri, 2013).

Employee performance. A person's willingness and skills are not effective enough to do something without a clear understanding of what is done and how to do it. Performance is a real behavior that is displayed by everyone as work performance produced by employees in accordance with their role in the company. Based on some understanding of employee performance that has been described by experts, it can be stated that employee performance is the achievement of employee work on the duties and authorities that have been given by the company in accordance with the capabilities and competencies of the employee both in terms of quantity and quality to achieve goals, vision and mission of the company. To determine employee performance, it is necessary to conduct a performance appraisal process. There are five parties that can assess employee performance, namely: direct supervisor, co-workers, self-evaluation, direct subordinates, a comprehensive approach that is 360 degrees (Robbins, 2015).

Hypotheses:

$\mathrm{H} 1$ : Organizational justice has a positive effect on organizational support;

$\mathrm{H} 2$ : Organizational support has a positive effect on employee engagement

H3: Organizational justice has a positive effect on employee engagement;

$\mathrm{H} 4$ : Employee engagement has a positive effect on employee performance.

\section{METHODS OF RESEARCH}

The population in this study were all sales employees of PT. Astra International Auto 2000 Cokroaminoto has 50 employees. This study uses saturated samples, namely all employees in the sales department of PT. Astra International Auto 2000 Cokroaminoto totaling 50 employees. To obtain the data to be examined, researchers used data collection techniques using a questionnaire. Likert scale can be used to measure attitudes, opinions or perceptions of a person or group of people towards social phenomena. This study uses descriptive statistics and inferential statistics for data analysis. Descriptive statistics are used to describe the demographic data of respondents presented through tables, average calculations, and percentage calculations, while inferential statistics are used to test 
hypotheses. This research uses SEM (Structural Equation Modeling) analysis technique based on component or variance, namely PLS (Partial Least Square).

\section{RESULTS AND DISCUSSION}

In this structural model, there are three dependent variables, namely: organizational support (X2), employee engagement (Y1), and employee performance (Y2). The coefficient of determination $\left(R^{2}\right)$ of each dependent variable can be presented in Table 1 below:

Table 1 - R-Square

\begin{tabular}{ll}
\hline Variable & R-Square \\
\hline Org. Support & 0.951 \\
\hline Employee Engagement & 0.917 \\
\hline Employee Performance & 0.978 \\
\hline
\end{tabular}

Source: Primary Data, 2018.

The R-square value of the organizational support construct of 0.951 in Table 5.9 can be interpreted that $95.10 \%$ of the construct variability of organizational support is explained by organizational justice, while $4.90 \%$ is explained by variables outside the model. Likewise, the employee engagement construct with R-square value of 0.917 means that $91.70 \%$ of the variability is explained by organizational justice and organizational support, while $8.30 \%$ is explained by variables outside the model. The R-square value of the employee performance construct of 0.978 can be interpreted that $97.80 \%$ of the construct variability of employee performance is explained by the employee engagement construct, while $2.80 \%$ is explained by variables outside the model.

This study uses the Partial Least Square (PLS) analysis approach to test and analyze the research hypotheses previously stated. The results of empirical research model analysis using Partial Least Square (PLS) analysis tools can be seen in Table 2.

Table 2 - Path Coefficients

\begin{tabular}{lllll}
\hline Hypotheses & Original Sample $(\mathrm{O})$ & $t$-statistic & $p$ Values & Description \\
\hline $\mathrm{H}_{1}$ & 0.989 & 179.706 & 0.000 & Sig. \\
\hline $\mathrm{H}_{2}$ & 0.438 & 2.274 & 0.006 & Sig. \\
\hline $\mathrm{H}_{3}$ & 0.540 & 2.784 & 0.000 & Sig. \\
\hline $\mathrm{H}_{4}$ & 0.958 & 35.744 & 0.023 & Sig. \\
\hline
\end{tabular}

Source: Primary Data, 2018.

Based on Table 2 it can be explained that organizational justice has a positive and significant effect on organizational support with a correlation coefficient of 0.989 and a statistical $t$ value of 179.706 ( $t$ value $179.706>t$ table 1.96). This means that the higher the organizational justice perceived by employees, the higher the organizational support they have. The results of this study indicate that managers or superiors must show fair attitude to all employees in accordance with their input and output so that employees feel supported by the organization that makes these employees do their jobs better. Organizations must show that they can be fair to each employee without differentiating them by developing policies that allow managers to make decisions fairly in fulfilling the rights and needs of their employees. The results of this study are supported by Fu (2012) which shows a significant relationship between organizational justice and perceived organizational support. A positive relationship between distributive justice and organizational support perceptions among managers of women who have a high and average level of awareness, but the effects of distributive justice and perceptions of organizational support are more apparent to managers of women with lower levels of awareness, who generally have perceptions of organizational support which is higher than those who have a low level of consciousness.

Organizational support has a positive and significant effect on employee engagement with a correlation coefficient of 0.438 and a statistical $t$ value of 2,274 ( $t$ value value 2,274> 
value of $t$ table 1,96). This means that the higher the perception of organizational support that the company has, the higher the level of engagement that employees have. The higher the organizational support perceived by employees, the higher the level of engagement that employees have. High perception of organizational support can increase the positive effects of employee engagement. Voluntary willingness of employees with positive emotions to be involved and drifting with their work is consistent with their positive perception of the support provided by their organization. Employee engagement is more likely to have a beneficial impact such as increased employee productivity if employees feel motivated by the support and attention of the company. The results of this study are supported by the results of research conducted by Saks (2006) regarding the relationship between the perceptions of organizational support and employe engagement shows that employees who feel a high level of support are more likely to have a level of attachment or engagement to their work or organization. The same research results were also shown by Ahmed (2015) who found that perceived support by employees would affect his engagement with the company. Rich (2010) in his research on 245 firefighters in four different places stated that individuals will feel more attached / demoted to their work if they have a high level of organizational support perception.

Organizational justice has a positive and significant effect on employee engagement with a correlation coefficient of 0.540 and a statistical $t$ value of 2.784 ( $t$ value of $2.784>t$ table value of 1.96). This means that the higher the organizational justice perceived by employees, the higher the engagement that is owned by the employee. In the organization, this is important especially in terms of distributing rewards to employees and the procedures used to allocate them. Distributive justice is related to one's perception of the outcome of the decision, to assess fair distribution or cannot be seen from the upholding of the applicable regulations. If the agreed decision is not carried out properly or partially, the justice will not be achieved. This will determine the level of employee engagement, if the justice perceived by employees is high then he will comply with the regulations made by the organization, then engagement will be achieved. The results of this study are supported by research conducted by Park et al. (2016) in his research showed a positive relationship between organizational justice and self-leadership and employee engagement. Today's companies need employees who have engagement to be key in creating change and resilience in the organization. Similar results were also expressed by Haifani et al. (2017) where procedural justice has a positive effect on employee engagement. Organizational justice factors that are felt by employees will certainly bring stronger employee engagement with their organization.

Employee engagement has a positive and significant effect on employee performance with a correlation coefficient of 0.958 and a t statistic value of 35.744 ( $t$ value $35.744>t$ table 1.96). This means that the better the engagement that the employee has, the better the performance of the employee. It is known that employee engagement is one of the important aspects that most affect employee performance, so that the availability of support at work is needed, feeling safe, fair and meaningful in the workplace. With this in mind, employees can feel engaged with the company and can improve their performance. Companies with engaged employees have relatively low turnover rates, high productivity and customer satisfaction. On the other hand, companies with employees who are not engaged are shown by low employee commitment, increased absenteeism and decreasing employee productivity. The results of this study supported by research conducted by Kazimoto (2016) in his research on employee engagement and organizational performance in 120 employees in the retail industry in Uganda showed that there was a positive and significant relationship between employee engagement and performance. A high level of employee engagement will be able to increase its involvement in work that will motivate employees to increase their productivity.

\section{CONCLUSION AND SUGGESTIONS}

Organizational justice has a positive and significant influence on organizational support. This means that the higher the organizational justice perceived by employees, the 
higher the organizational support felt by employees. The results of this study indicate that managers or superiors must pay more attention and support employees to enable them to do work better.

Organizational support perceived by employees has a positive and significant effect on employee engagement. This means that the higher the organizational support perceived by employees, the higher the level of employee engagement that is owned by employees. Perception of high organizational support can increase the positive effects of employee engagement on employee productivity.

Organizational justice has a positive and significant effect on employee engagement. This means that the higher the organizational justice perceived by employees, the higher the employee engagement owned by employees. In the organization this is important to do especially in terms of distributing rewards to employees and the procedures used to allocate them.

Employee engagement has a positive and significant effect on employee performance. This means that the higher the employee engagement that is owned by the employee, the better the performance of the employee. It is known that employee engagement is one of the things that most influences employee performance, so that the availability of support at work is needed, feeling safe, fair and meaningful in the workplace. With this in mind, employees can feel engaged with the company and can improve their performance.

Future research needs to consider using other constructs such as organizational culture and leadership that can be predictors of employee engagement and how it affects employee performance. Based on the results of the study, the authors suggest that it is expected that in the next research it is necessary to examine the AUTO 2000 companies in other branches or can use research respondents on employees who work in government agencies. Then it can be compared to the variables of organizational justice, organizational support, employee engagement and employee performance in private employees and civil servants.

Based on research that has been done several limitations in this study. Only limited to the AUTO 2000 company research at Cokroaminoto, this research cannot be generalized to other AUTO 2000 branch companies. Time limitations make the writer only able to research only one branch. It is expected that the next research needs to be examined in AUTO 2000 other branch companies or can use research respondents to employees who work in government agencies. Then it can be compared to the variables of organizational justice, organizational support, employee engagement and employee performance in private employees and civil servants.

\section{REFERENCES}

1. Ahmed, Ishfaq and Nawaz, Muhammad M. 2015. Antecedents and outcomes of perceived organizational support: a literature survey approach. Journal of Management Development. Vol. 34 No. 7, pp. 867-880.

2. Ardi, Venna T.P., Astuti, Endang S. dan Sulistyo, M. Cahyo. 2017. Pengaruh Self Efficacy Employee Engagement dan Kinerja Karyawan (Studi pada Karyawan PT Telekomunikasi Indonesia Regional V Surabaya). Jurnal Administrasi Bisnis. Vol. 52 No. 1.

3. Bowles, D., \& Cooper, C. 2009. Employee morale: Driving performance in challenging times. Basingstoke: Palgrave Macmillan.

4. Fatimah, O., Amiraa, A M., and Halim, F W. 2011. The Relationships between Organizational Justice, Organizational Citizenship Behavior and Job Satisfaction.Pertanika J. Soc. Sci. \& Hum, 9, pp: 115-121.

5. Farahbod, Farzin,. Azadehdel, M.R., dan Jirdehi, M.N. 2013. Organizational justice, employees trust and organizational support. Kuwait Chapter of Arabian Journal of Business and Management Review. Vol. 3, No.2.

6. Forootan, Farideh. 2012. The role of perceived organizational support and career opportunities as moderators of the relationship between work engagement and job 
satisfaction. Thesis. The Faculty of the Department of Psychology San José State University

7. Fu, Yang and Lihua, Zhang. 2012. Organizational justice and perceived organizational support the moderating role of conscientiousness in China. Nankai Business Review International. Vol. 3 No. 2, pp. 145-166.

8. Gallup. 2008. Employee Engagement - What's Your Engagement Ratio?. Gallup Inc.

9. Gallup. 2004. Study Engaged Employees Inspire Company Innovation. Gallup Management Journal.

10. Greenberg, Jerald \& Robert A. Baron. 2003. Behaviour in organization, understanding and managing the human side of work. Third Edition. Allin and Bacon. A Division of Schuster. Massachuscets.

11. Kazimoto, Paluku. 2016. Employee Engagement and Organizational Performance of Retails Enterprises. American Journal of Industrial and Business Management. Vol. 6, Pg. 516-525

12. Macey, W.H., B. Schneider., K.M Barbera., S.A Young. 2009. Employee Engagement: Tools for Analysis, Practice, and Competitive Advantage. United States: Wiley-Blackwell

13. Markos, Solomon and Sridevi, Sandhya M. 2010. Employee Engagement: The Key to Improving Performance. International Journal of Business and Management. Vol. 5, No. 12

14. Margaretha, Meily \& T. Elisabeth, Cintya Santosa. 2012. Keadilan procedural dan keadilan distributif sebagai prediktor employee engagement. Jurnal Manajemen, Vol.12, No.1, pp 103-114.

15. Mathis, R.L. dan Jackson, J.H. 2006. Human Resource Management, Terjemahan, Edisi Kesepuluh. Jakarta: Salemba Empat.

16. Park, Yukyung., Song, Ji Hoon., Lim, Doo Hun. 2016. Organizational justice and work engagement: the mediating effect of self-leadership. Leadership \& Organization Development Journal. Vol. 37, Iss. 6, 711-729.

17. Putri, Vicentia dan Liestiawati, Fibria. 2013. Pengaruh employee engagement terhadap organizational citizenship behavior pada karyawan PT. sepatu bata, Tbk.. Jurnal Universitas Indonesia. 3, 17-25.

18. Rasheed, Adnan., Khan, Sanam,. And Ramzan, Muhammad. 2013. Antecedents and Consequences of Employee Engagement: The Case of Pakistan. Journal of Business Studies Quarterly. Vol. 4, No. 4. Pp 183-200.

19. Rich, Bruce L., Lepine, J.A., and Crawford, Eean R. 2010. Job engagement : antecedents and effects on job performance. Academy of Management Journal. Vol. 53, No. 3, Pp. 617-635.

20. Saks, A.M. 2006. Antecedents and consequences of employee engagement. Journal of Managerial Psychology. Vol. 21 No. 7, pp. 600-619.

21. Saroyeni Piartrini, Putu. Keterikatan Karyawan Merupakan Alternatif, Ketika Kepuasan Kerja dan Komitmen Tidak Cukup Untuk Meningkatkan Kinerja Organisasi. Piramida. [S.I.], Nov. 2012. ISSN 1907-3275

22. Scheimann, W.A. 2011. Alignment, capability, engagement: pendekatan baru talent management untuk mendongkrak kinerja organisasi. Penerjemah : Setyo Untoro. Jakarta. Penerbit PPM.

23. Sekarwangi, Endah dan Meiyanto, Sito. 2014. Pengaruh Stress Kerja dan Keadilan Organisasi terhadap Employee engagement. Jurnal Psikologi Universitas Gadjah Mada. Vol. 2.

24. Ulrich, D. 2007. The talent trifecta. Workforce Management, 86(15), 32-33.

25. Welch, Mary. 2011. The evolution of the employee engagement concept: communication implications. Corporate Communications: An International Journal. Vol. 16 No. 4, pp. 328-346

26. Yasar, M.F., Emhan, Abdurrahim and Ebere, Pauline. 2014. Analysis of Organizational Justice, Supervisor Support, and Organizational Commitment: A Case Study of Energy Sector in Nigeria. Journal of Business Studies Quarterly. Vol. 5, No. 3. 